\title{
NOTE
}

\section{Ocean acidification rapidly reduces dinitrogen fixation associated with the hermatypic coral Seriatopora hystrix}

\author{
Nils Rädecker ${ }^{1,2 *}$, Friedrich W. Meyer ${ }^{1}$, Vanessa N. Bednarz ${ }^{1}$, Ulisse Cardini ${ }^{1}$, \\ Christian Wild ${ }^{1,2}$
}

\author{
${ }^{1}$ Leibniz Center for Tropical Marine Ecology (ZMT), Fahrenheitstr. 6, 28359 Bremen, Germany \\ ${ }^{2}$ Faculty of Biology and Chemistry (FB2), PO Box 330440, University of Bremen, 28334 Bremen, Germany
}

\begin{abstract}
Since productivity and growth of coral-associated dinoflagellate algae is nitrogen (N)-limited, dinitrogen $\left(\mathrm{N}_{2}\right)$ fixation by coral-associated microbes is likely crucial for maintaining the coral-dinoflagellate symbiosis. It is thus essential to understand the effects future climate change will have on $\mathrm{N}_{2}$ fixation by the coral holobiont. This laboratory study is the first to investigate short-term effects of ocean acidification on $\mathrm{N}_{2}$ fixation activity associated with the tropical, hermatypic coral Seriatopora hystrix using the acetylene reduction assay in combination with calcification measurements. Findings reveal that simulated ocean acidification ( $\left.p \mathrm{CO}_{2} 1080 \mu \mathrm{atm}\right)$ caused a rapid and significant decrease $(53 \%)$ in $\mathrm{N}_{2}$ fixation rates associated with $S$. hystrix compared to the present day scenario $\left(p \mathrm{CO}_{2} 486 \mu \mathrm{atm}\right)$. In addition, $\mathrm{N}_{2}$ fixation associated with the coral holobiont showed a positive exponential relationship with its calcification rates. This suggests that even small declines in calcification rates of hermatypic corals under high $\mathrm{CO}_{2}$ conditions may result in decreased $\mathrm{N}_{2}$ fixation activity, since these 2 processes may compete for energy in the coral holobiont. Ultimately, an intensified $\mathrm{N}$ limitation in combination with a decline in skeletal growth may trigger a negative feedback loop on coral productivity exacerbating the negative long-term effects of ocean acidification.
\end{abstract}

KEY WORDS: Acetylene reduction assay - Nutrient limitation - Carbon fixation · Calcification · Coral holobiont

\section{INTRODUCTION}

Hermatypic corals are highly adapted to the oligotrophic waters in which they occur by forming a mutualistic symbiosis with dinoflagellate algae of the genus Symbiodinium (Muscatine \& Porter 1977). Although this symbiosis enables an efficient internal recycling of nutrients, new nutrients (particularly bioavailable nitrogen) are needed to sustain net productivity and to compensate the loss of nutrients. New nitrogen $(\mathrm{N})$ is acquired by the coral holobiont

${ }^{*}$ Corresponding author: nils.raedecker@zmt-bremen.de via capture of prey, assimilation of inorganic and organic $\mathrm{N}$ from the water column, and dinitrogen $\left(\mathrm{N}_{2}\right)$ fixation (Lesser et al. 2007, Grover et al. 2008). In this context, Lesser et al. (2004) for the first time detected endosymbiotic cyanobacteria in the coral Montastraea cavernosa. Recent research revealed that diazotrophs $\left(\mathrm{N}_{2}\right.$ fixing bacteria and archaea) are ubiquitous members of coral-associated microbial communities and form species-specific associations with their hosts (Lema et al. 2012, 2014, Olson \& Lesser 2013). $\mathrm{N}_{2}$ fixation activity has also been detected for several coral

() The authors 2014. Open Access under Creative Commons by Attribution Licence. Use, distribution and reproduction are unrestricted. Authors and original publication must be credited. 
species, suggesting a high importance of this process in fulfilling the $\mathrm{N}$ demand of corals (reviewed in Fiore et al. 2010 and Cardini et al. 2014).

Since growth of Symbiodinium spp. is N limited, low dissolved inorganic N (DIN) availability may be essential to maintain the stability of this symbiosis (Falkowski et al. 1993). On the other hand, Symbiodinium spp. is efficient in the uptake of fixed $\mathrm{N}$ (Kopp et al. 2013), and cell division rates are faster in corals that show high $\mathrm{N}_{2}$ fixation activity (Lesser et al. 2007). Hence, $\mathrm{N}_{2}$ fixation may play a key role in regulating the coral-dinoflagellate symbiosis. The effects of environmental changes, such as ocean acidification, on $\mathrm{N}_{2}$ fixation associated with hermatypic corals have yet to be resolved. Several studies reported reduced calcification rates under high $\mathrm{CO}_{2}$ conditions and reduced aragonite saturation (Cohen \& Holcomb 2009, Ries et al. 2009, Crook et al. 2013). Even though positive as well as negative effects of ocean acidification on $\mathrm{N}_{2}$ fixation activity by planktonic diazotrophs have been reported (Levitan et al. 2007, Czerny et al. 2009, Shi et al. 2012), there are no studies up to now investigating the effects of ocean acidification on $\mathrm{N}_{2}$ fixation associated with hermatypic corals. Thus, in the present study we experimentally investigated the short-term response of $\mathrm{N}_{2}$ fixation and calcification (light/dark) in the exemplary coral holobiont Seriatopora hystrix exposed to high $\mathrm{CO}_{2}$ conditions as they may occur before 2100 according to the Intergovernmental Panel on Climate Change (IPCC) scenario RCP 8.5 (Riahi et al. 2007).

\section{MATERIALS AND METHODS}

\section{Model organism and sample preparation}

The hermatypic coral Seriatopora hystrix was selected as model organism for this study as it is abundant, occurs in a wide range of habitats, and is frequently used in physiological studies (Sheppard 1987, Hoegh-Guldberg \& Smith 1989, Bongaerts et al. 2011). The coral used for the experiment was acquired from the company De Jong Marinelife (Netherlands) and was collected from a shallow water depth of about $5 \mathrm{~m}$ in Indonesia. One individual colony was fragmented into 30 smaller colonies of an average size of $11.75 \pm 1.12 \mathrm{~cm}^{2}$ (mean $\pm \mathrm{SE}$ ) to remove genetic variability. All fragments were kept in a mesocosm holding tank (2000 l) in the laboratory facilities of the Leibniz Centre for Tropical Marine Ecology (ZMT, Bremen) for 2 mo prior to the measurements.

\section{Experimental incubations}

The seawater used for the $\mathrm{CO}_{2}$ treatment was taken from the coral holding tank, filtered $(0.1 \mu \mathrm{m}$, AcroPak ${ }^{\mathrm{TM}}$ ) and equilibrated with gas of defined $\mathrm{CO}_{2}$ concentrations of either $486 \mathrm{ppm}$ by volume (ppmv; ambient) or $1080 \mathrm{ppmv}$ (high). The resulting changes in seawater carbonate chemistry were calculated from $\mathrm{pH}$ (NBS) and total alkalinity (TA) using the $\mathrm{CO}_{2}$ Sys Excel Macro (Lewis \& Wallace 1998). pH (NBS) reading was obtained from a multiprobe (WTW 3430) and TA was measured by end-point titration with TW alpha plus (SI Analytics) using $0.5 \mathrm{M} \mathrm{HCl}$. Corals were exposed to the $\mathrm{CO}_{2}$ treatment in holding tanks for $20 \mathrm{~h}$ prior to the first incubations and for $24 \mathrm{~h}$ in between the first and the second incubation (salinity $34 \%$, temperature $26^{\circ} \pm 1^{\circ} \mathrm{C}$, PAR $110 \pm 5$ quanta $\mu \mathrm{mol} \mathrm{s} \mathrm{s}^{-1} \mathrm{~m}^{-2}$ ). Additionally seawater at ambient or high $\mathrm{CO}_{2}$ was used during the incubations, respective to the treatment. Calcification, photosynthesis, respiration and $\mathrm{N}_{2}$ fixation rates were measured in 2 consecutive incubations. A total of 30 fragments were incubated with $\mathrm{n}=15$ for each $\mathrm{CO}_{2}$ treatment level (ambient and high). Firstly, $\mathrm{O}_{2}$ fluxes and calcification rates under treatment conditions (seawater of ambient or high $\mathrm{CO}_{2}$ ) were quantified during the same incubation. Oxygen fluxes of the coral fragments were measured during light (PAR $110 \pm 5$ quanta $\mu \mathrm{mol} \mathrm{s}^{-1}$ $\mathrm{m}^{-2}$ ) and dark incubations $(<2 \mathrm{~h}$ each to avoid supersaturation of $\mathrm{O}_{2}$ ) in $250 \mathrm{ml}$ glass chambers by constant logging of $\mathrm{O}_{2}$ concentrations using $\mathrm{O}_{2}$ optodes (Firesting, PyroScience Sensor Technology). Water samples of $50 \mathrm{ml}$ were collected from each chamber before and after each incubation (light/dark) to measure calcification rates. All coral fragments were returned to the treatment aquaria of high or ambient $\mathrm{CO}_{2}$, according to the treatment, for $24 \mathrm{~h}$ before start of the second incubation.

In the second incubation, the acetylene reduction technique was used to quantify $\mathrm{N}_{2}$ fixation rates of the coral fragments (Hardy et al. 1968, Wilson et al. 2012). Coral fragments were incubated in 11 glass chambers filled with $800 \mathrm{ml}$ of treatment water (ambient or high $\mathrm{CO}_{2}$ respectively), of which $10 \%(80 \mathrm{ml})$ was previously saturated with acetylene $\left(\mathrm{C}_{2} \mathrm{H}_{2}\right)$ to improve equilibration in the chamber. Also, $10 \%(20 \mathrm{ml})$ of the $200 \mathrm{ml}$ headspace was replaced with $\mathrm{C}_{2} \mathrm{H}_{2}$ gas after the chambers were sealed gastight. The incubation lasted for $22 \mathrm{~h}$, starting with a $12 \mathrm{~h}$ dark phase followed by a $10 \mathrm{~h}$ light phase. During incubation, chambers were kept at a constant temperature of $26.0^{\circ} \pm$ $0.3^{\circ} \mathrm{C}$. Gas samples of $1 \mathrm{ml}$ were taken from the headspace after intervals of $0,4,12$ and $22 \mathrm{~h}$, and collected 
in $2 \mathrm{ml}$ glass vials previously filled with deionized water. Vials were stored frozen upside down until analysis to prevent any leakage from the septa.

\section{Sample analyses}

Respiration and gross photosynthesis rates were calculated from the incubation periods which showed linear changes in $\mathrm{O}_{2}$ concentration. Changes in the total alkalinity of the water samples before and after the incubations were converted into calcification rates using the alkalinity anomaly technique (Chisholm \& Gattuso 1991). Nitrogen fixation rates were calculated as ethylene $\left(\mathrm{C}_{2} \mathrm{H}_{4}\right)$ evolution rates and not converted into actual fixation rates of $\mathrm{N}_{2}$, as we acknowledge that there is an ongoing discussion about the correct conversion factor in the scientific community (Nohrstedt 1983, Wilson et al. 2012). $\mathrm{C}_{2} \mathrm{H}_{4}$ concentrations in the gas samples were quantified by gas chromatography (Varian 3800 with AL203/KCL $50 \times 0.53$ column and flame ionization detector). Changes in $\mathrm{C}_{2} \mathrm{H}_{4}$ concentration were converted into $\mathrm{C}_{2} \mathrm{H}_{4}$ evolution rates according to Breitbarth et al. (2004). $\mathrm{N}_{2}$ fixation rates showed a distinct initial lag phase during the first $4 \mathrm{~h}$ of incubation. This is a common phenomenon during acetylene reduction assays (Zuberer \& Silver 1978, Gallon \& Hamadi 1984, Shashar et al. 1994b). Hence, $\mathrm{N}_{2}$ fixation rates for the dark phase were calculated based on $\mathrm{C}_{2} \mathrm{H}_{4}$ concentration differences during the second time interval ( 4 to $12 \mathrm{~h}$ ) without considering the first $4 \mathrm{~h}$ of incubation. Light $\mathrm{N}_{2}$ fixation rates were calculated based on concentration differences between 12 and $22 \mathrm{~h}$ of incubation time.

Photosynthesis, respiration, calcification and $\mathrm{N}_{2}$ fixation rates were corrected for seawater control $(\mathrm{n}=$ 6) signals and normalized to incubation time and coral surface area, which was quantified by advanced geometry (Naumann et al. 2009).

\section{Data analysis}

All statistical analyses were conducted with $\mathrm{R}$ version 3.0.2 (R Development Core Team 2013). Differences in $\mathrm{N}_{2}$ fixation rates were analysed using generalized mixed effect linear models (GLMM) with gamma distribution and an inverse link function taking into account minor fluctuations in water temperatures during the incubations to increase the fit of the model. $\mathrm{O}_{2}$ fluxes, calcification rates and the relationship of calcification with $\mathrm{N}_{2}$ fixation rates were also analysed with generalized linear models (GLM) with gamma distribution and an inverse link function. To meet the assumptions of gamma distribution, $\mathrm{O}_{2}$ fluxes, calcification and $\mathrm{N}_{2}$ fixation rates were $(x+1)$ transformed. All data were corrected for outliers using the Dixon test.

\section{RESULTS}

The seawater carbonate system following the manipulation of $\mathrm{CO}_{2}$ concentrations showed significant differences. At a total alkalinity of $1784 \pm 36 \mu \mathrm{mol}$ $\mathrm{kg}^{-1}$ seawater, ambient $\mathrm{CO}_{2}$ concentrations resulted in an aragonite saturation state $(\Omega \mathrm{Ar})$ of $1.9 \pm 0.1$ at a $\mathrm{pH}$ of 8.02, whereas high $\mathrm{CO}_{2}$ concentrations showed an $\Omega$ Ar of $1.0 \pm 0$ at a $\mathrm{pH}$ of 7.71 .

Short term exposure to high $\mathrm{CO}_{2}$ concentrations revealed strong effects on the physiology of fragments of Seriatopora hystrix compared to the fragments incubated under ambient $\mathrm{CO}_{2}$ concentrations. $\mathrm{N}_{2}$ fixation activity (acetylene reduction) was variable, but measurable in all coral fragments. Rates were higher (3 to 4 times) in the light than in the dark, independently of the treatment applied $\left(\chi_{(1, \mathrm{~N}=30)}^{2}=22.839, \mathrm{p}<<\right.$ $0.001) . \mathrm{N}_{2}$ fixation rates ranged from $0.04-1.98$ and
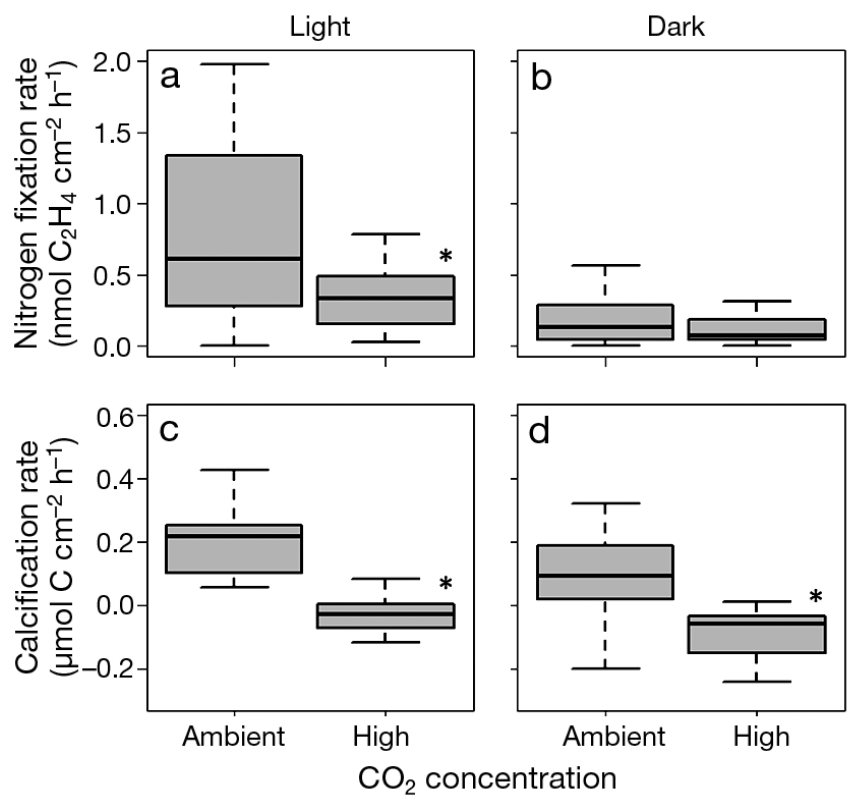

Fig. 1. $(a, b) N_{2}$ fixation rates $(n=15)$ and $(c, d)$ calcification rates $(\mathrm{n}=13)$ of Seriatopora hystrix under ambient and high $\mathrm{CO}_{2}$ concentration treatments during the $\left(\mathrm{a}_{1} \mathrm{c}\right)$ light period and $(b, d)$ dark period. $\mathrm{N}_{2}$ fixation rates = ethylene $\left(\mathrm{C}_{2} \mathrm{H}_{4}\right)$ production rates. Rates were corrected for seawater control and normalized to incubation time and coral surface area. Boxplot: mean, upper and lower quartiles; whiskers: data points within 1.5 times the interquartile range from the box. ${ }^{*} \mathrm{p}<0.01$ significantly different from each other 
0.00-0.56 $\mathrm{nmol} \mathrm{C}_{2} \mathrm{H}_{4} \mathrm{~cm}^{-2} \mathrm{~h}^{-1}$ during the light and dark period, respectively (Fig. 1a,b). High $\mathrm{CO}_{2}$ levels caused a significant decline $(53 \%)$ in the $\mathrm{N}_{2}$ fixation rates of the coral holobiont in the light $\chi_{(1, \mathrm{~N}=30)}^{2}=6.8271, \mathrm{p}<$ 0.01 ), reducing from $0.83 \pm 0.16$ (ambient) to $0.39 \pm$ $0.09 \mathrm{nmol} \mathrm{C}_{2} \mathrm{H}_{4} \mathrm{~cm}^{-2} \mathrm{~h}^{-1}$ (high). This was not the case in the dark, because rates were too low to indicate any significant differences $\left(\chi_{(1, N=30)}^{2}=0.8311, p=0.36\right)$.

Overall, calcification rates ranged from -0.12 to $0.42 \mu \mathrm{mol} \mathrm{C} \mathrm{cm} \mathrm{C} \mathrm{h}^{-1}$ in the light and -0.24 to $0.32 \mu \mathrm{mol} \mathrm{C} \mathrm{cm} \mathrm{Cm}^{-2} \mathrm{~h}^{-1}$ in the dark period (Fig. 1c,d). Calcification rates showed a pronounced response to differences in $\mathrm{CO}_{2}$ concentrations, significantly reducing under high $\mathrm{CO}_{2}$ conditions compared to ambient $\mathrm{CO}_{2}$ levels both in the light $\left(\chi_{(1, N=26)}^{2}=\right.$ $26.651, \mathrm{p}<<0.001)$ and in the dark period $\left(\chi_{(1, \mathrm{~N}=26)}=\right.$ $4.55, \mathrm{p}<<0.001)$. At ambient $\mathrm{CO}_{2}$ concentrations, calcification rates were $0.20 \pm 0.03 \mu \mathrm{mol} \mathrm{C} \mathrm{cm}{ }^{-2} \mathrm{~h}^{-1}$ in the light and $0.09 \pm 0.04 \mu \mathrm{mol} \mathrm{C} \mathrm{cm}{ }^{-2} \mathrm{~h}^{-1}$ in the dark period. At high $\mathrm{CO}_{2}$ concentrations, calcification rates were $-0.01 \pm 0.03 \mu \mathrm{mol} \mathrm{C} \mathrm{cm}{ }^{-2} \mathrm{~h}^{-1}$ in the light and $-0.08 \pm 0.02 \mu \mathrm{mol} \mathrm{C} \mathrm{cm}{ }^{-2} \mathrm{~h}^{-1}$ in the dark. Since both calcification and $\mathrm{N}_{2}$ fixation decreased under the ocean acidification scenario, the relationship between these 2 processes was investigated (Fig. 2).

This revealed a positive exponential correlation of $\mathrm{N}_{2}$ fixation activity and calcification rates in coral

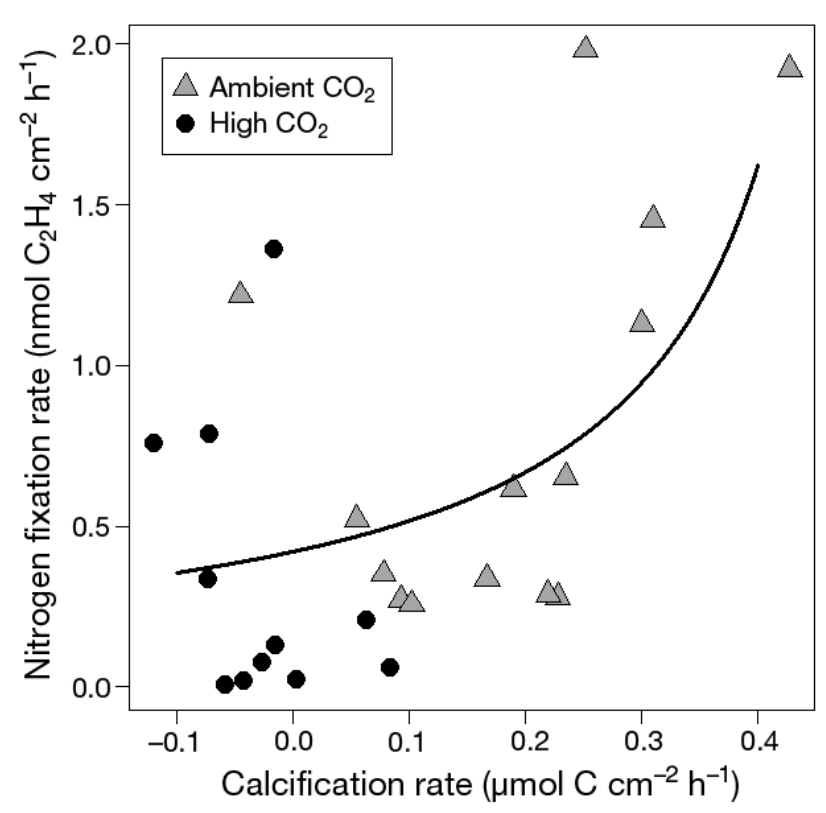

Fig. 2. Relationship of $\mathrm{N}_{2}$ fixation rates and calcification rates of Seriatopora hystrix incubated in the light under high $\mathrm{CO}_{2}(\bullet)$ and ambient conditions $(\Delta)$. All rates were corrected for seawater controls and normalized to incubation time and coral surface area. Black curve: best-fitting model $\left(\chi_{(1, N=25)}^{2}=5.21, p=0.03\right.$, McFadden's $\left.R^{2}=0.862\right)$ fragments incubated in the light $\chi_{(1, \mathrm{~N}=25)}^{2}=5.21, \mathrm{p}=$ 0.02 ) as opposed to dark incubations (not shown), where the relationship was not significant $\left(\chi_{(1, \mathrm{~N}=25)}^{2}=\right.$ $0.35, \mathrm{p}=0.55$ ).

Differences in $\mathrm{CO}_{2}$ concentrations had no significant effect on gross photosynthesis $\left(\chi_{(1, \mathrm{~N}=30)}^{2}=0.01\right.$, $\mathrm{p}=0.90)$ and respiration rates $\left(\chi_{(1, \mathrm{~N}=30)}^{2}=0.18, \mathrm{p}=\right.$ 0.67 ) of the coral nubbins (not shown). Mean gross photosynthesis was $0.50 \pm 0.04 \mu \mathrm{mol} \mathrm{O}_{2} \mathrm{~cm}^{-2} \mathrm{~h}^{-1}$ under high $\mathrm{CO}_{2}$ compared to $0.49 \pm 0.05 \mu \mathrm{mol} \mathrm{O}_{2}$ $\mathrm{cm}^{-2} \mathrm{~h}^{-1}$ under ambient $\mathrm{CO}_{2}$ conditions. Respirations rates were $-0.30 \pm 0.03$ and $-0.28 \pm 0.2 \mu \mathrm{mol} \mathrm{O}_{2} \mathrm{~cm}^{-2}$ $\mathrm{h}^{-1}$ at high and low $\mathrm{CO}_{2}$ conditions respectively.

\section{DISCUSSION}

This is the first study showing $\mathrm{N}_{2}$ fixation associated with Seriatopora hystrix and demonstrating the effect of elevated $\mathrm{CO}_{2}$ levels on $\mathrm{N}_{2}$ fixation.

$\mathrm{N}_{2}$ fixation has been described for several other coral species, with a pronounced variation between and within species (Williams et al. 1987, Shashar et al. 1994b, Lesser et al. 2007). To control for the intra-specific differences, manipulative experiments need to use individuals of identical genotype (Mascarelli \& Bunkley-Williams 1999). All experiments in this study where conducted with coral colonies from the same colony. Thus the observed physiological changes can be referred back to treatment conditions.

$\mathrm{N}_{2}$ fixation is an energy-intensive process (McNary \& Burris 1962). Shashar et al. (1994a) found that $\mathrm{N}_{2}$ fixation activity was inhibited in corals when photosynthesis was blocked with DCMU $(3-[3,4$-dichlorophenyl]-1,1-dimethylurea), but could be restored when glucose was added to the incubation water. This suggests that coral associated $\mathrm{N}_{2}$ fixation strongly depends on photosynthetically fixed carbon to fulfil its energetic demands. In the present study, $\mathrm{N}_{2}$ fixation rates were 3 to 4 times higher during the light incubations compared to the dark. This is likely explained by increased availability of fixed carbon by photosynthesis during the light phase. $\mathrm{N}_{2}$ fixation occurred during times of net $\mathrm{O}_{2}$ evolution, although $\mathrm{O}_{2}$ is known to inhibit this process (Gallon 1981). There are different mechanisms by which $\mathrm{N}_{2}$ fixation can take place at times of $\mathrm{O}_{2}$ evolution (Gallon 1981). In coral reef sponges, for example, symbiotic nonheterocystous cyanobacteria, which depend on $\mathrm{O}_{2}$ for their $\mathrm{N}_{2}$ fixation, have been suggested to explain high $\mathrm{N}_{2}$ fixation activity under aerobic conditions (Wilkinson \& Fay 1979, Mohamed et al. 2008). 
$\mathrm{N}_{2}$ fixation rates were significantly reduced in the ocean acidification treatment compared to the ambient scenario in the light. Other studies reported an increase of $\mathrm{N}_{2}$ fixation activity under elevated $\mathrm{CO}_{2}$ conditions for planktonic cyanobacteria due to increased photosynthetic carbon fixation by overcoming $\mathrm{CO}_{2}$ limitation (Hutchins et al. 2007, Garcia et al. 2013). This may be the case for planktonic autotrophic diazotrophs, but $\mathrm{CO}_{2}$ limitation is unlikely to occur in the $S$. hystrix holobiont due to respiration by the coral host. Reduced $\mathrm{N}_{2}$ fixation rates under elevated $\mathrm{CO}_{2}$ concentrations have only been described in the planktonic cyanobacterium Trichodesmium in combination with low iron availability (Shi et al. 2012). Since the experiments carried out in the present study took place in laboratory conditions, it is unlikely that iron limitation caused the lowering of fixation rates in the short time span of the experiment described in the present study. Hence, there has to be another cause for the effects observed. Along with $\mathrm{N}_{2}$ fixation, calcification of $S$. hystrix was significantly reduced during both light and dark periods. The significant positive correlation between both processes during the light may suggest an indirect linkage of the 2 processes in the holobiont.

The reduced calcification rates are in good agreement with previous studies reporting similar effects under low $\mathrm{pH}$ conditions due to lowered aragonite saturation state (Orr et al. 2005, Anthony et al. 2008, Kleypas \& Yates 2009). Since $\mathrm{N}_{2}$ fixation and calcification are energy-intensive mechanisms, they likely compete for energy within the coral holobiont. The lowering in the aragonite saturation state makes the calcification process more energy consuming (Marubini et al. 2001, Hohn \& Merico 2012). Since gross and net photosynthesis were not significantly different between treatments, the increased energy demand by calcification at high $\mathrm{CO}_{2}$ conditions may create an energy deficit in the coral holobiont. Subsequently, this may also reduce the energy available for heterotrophic diazotrophs in the coral tissue, thereby explaining the decrease in $\mathrm{N}_{2}$ fixation activity at high $\mathrm{CO}_{2}$ conditions. Although Anthony et al. (2008) reported a loss of coral productivity at lower seawater $\mathrm{pH}$ during long term experiments, there was no effect of elevated $\mathrm{CO}_{2}$ on photosynthesis and respiration of the fragments used in the present study, probably due to the short time span of the incubations. It is hence likely that the described long term drop in productivity will amplify the effects of ocean acidification on $\mathrm{N}_{2}$ fixation and calcification even more. This is the first evidence that coral associated $\mathrm{N}_{2}$ fixation can be affected by ocean acidification. The observed decline in $\mathrm{N}_{2}$ fixation may result in $\mathrm{N}$ starvation for both the coral and Symbiodinium spp. Together with a reduced skeletal growth, this suggests a negative feedback loop for the productivity of the holobiont. The reduction in $\mathrm{N}_{2}$ fixation may thus exacerbate negative long-term effects of ocean acidification for coral reef functioning. Finally, these findings highlight the importance of $\mathrm{N}_{2}$ fixation as a key process for understanding the response of the coral holobiont to environmental stressors such as ocean acidification. To improve the understanding of interactions between diazotrophs, Symbiodinium spp. and the coral host, an interdisciplinary approach is needed, combining ecological and microbiological aspects.

Acknowledgements. We thank Dr. Achim Meyer for his help with the realisation of the experimental set up and Dieter Peterke for his support during the sample analysis. For their support during the experiments we kindly acknowledge the student assistants of the Coral Reef Ecology group: Nur Herrea Garcia, Helen O'Neill, Florian Roth and Sabrina Schmalz. We especially thank the editor and the 3 anonymous reviewers, whose suggestions strongly contributed to the quality of this manuscript. This study was supported by German Research Foundation (DFG) grant Wi 2677/6-1 to C.W.

\section{LITERATURE CITED}

Anthony KRN, Kline DI, Dove S (2008) Ocean acidification causes bleaching and productivity loss in coral reef builders. Proc Natl Acad Sci USA 105:17442-17446

Bongaerts P, Riginos C, Hay KB, Van Oppen MJH, HoeghGuldberg O, Dove S (2011) Adaptive divergence in a scleractinian coral: physiological adaptation of Seriatopora hystrix to shallow and deep reef habitats. BMC Evol Biol 11:303

> Breitbarth E, Mills MM, Friedrichs G, Laroche J (2004) The Bunsen gas solubility coefficient of ethylene as a function of temperature and salinity and its importance for nitrogen. Limnol Oceanogr Methods 2:282-288

Cardini U, Bednarz VN, Foster RA, Wild C (2014) Benthic $\mathrm{N}_{2}$ fixation in coral reefs and the potential effects of humaninduced environmental change. Ecol Evol 4:1706-1727

Chisholm JRM, Gattuso JP (1991) Validation of the alkalinity anomaly technique for investigating calcification and photosynthesis in coral reef communities. Limnol Oceanogr $36: 1232-1239$

> Cohen A, Holcomb M (2009) Why corals care about ocean acidification: uncovering the mechanism. Oceanography 22(4):118-127

> Crook ED, Cohen AL, Rebolledo-Vieyra M, Hernandez L, Paytan A (2013) Reduced calcification and lack of acclimatization by coral colonies growing in areas of persistent natural acidification. Proc Natl Acad Sci USA 110: 11044-11049

> Czerny J, Barcelos e Ramos J, Riebesell U (2009) Influence of elevated $\mathrm{CO}_{2}$ concentrations on cell division and nitrogen fixation rates in the bloom-forming cyanobacterium Nodularia spumigena. Biogeosciences 6:1865-1875

Falkowski PG, Dubinsky Z, Muscatine L, McCloskey L 
(1993) Population control in symbiotic corals. Bioscience 43:606-611

> Fiore CL, Jarett JK, Olson ND, Lesser MP (2010) Nitrogen fixation and nitrogen transformations in marine symbioses. Trends Microbiol 18:455-463

Gallon JR (1981) The oxygen sensitivity of nitrogenase: a problem for biochemists and micro-organisms. Trends Biochem Sci 6:19-23

Gallon JR, Hamadi F (1984) Studies on the effects of oxygen on acetylene reduction (nitrogen fixation) in Gloeothece. J Gen Microbiol 130:495-503

Garcia NS, Fu F, Hutchins DA (2013) Colimitation of the unicellular photosynthetic diazotroph Crocosphaera watsonii by phosphorus, light, and carbon dioxide. Limnol Oceanogr 58:1501-1512

Grover R, Maguer JF, Allemand D, Ferrier-Pagès C (2008) Uptake of dissolved free amino acids by the scleractinian coral Stylophora pistillata. J Exp Biol 211:860-865

Hardy RWF, Holsten RD, Jackson EK, Burns RC (1968) The acetylene-ethylene assay for $\mathrm{N}_{2}$ fixation: laboratory and field evaluation. Plant Physiol 43:1185-1207

> Hoegh-Guldberg O, Smith GJ (1989) The effect of sudden changes in temperature, light and salinity on the population density and export of zooxanthellae from the reef corals Stylophora pistillata Esper and Seriatopora hystrix Dana. J Exp Mar Biol Ecol 129:279-303

> Hohn S, Merico A (2012) Effects of seawater $p \mathrm{CO}_{2}$ changes on the calcifying fluid of scleractinian corals. Biogeosciences Discuss 9:2655-2689

> Hutchins DA, Fu FX, Zhang Y, Warner ME and others (2007) $\mathrm{CO}_{2}$ control of Trichodesmium $\mathrm{N}_{2}$ fixation, photosynthesis, growth rates, and elemental ratios: implications for past, present, and future ocean biogeochemistry. Limnol Oceanogr 52:1293-1304

Kleypas JS, Yates KK (2009) Coral reefs and ocean acidification. Oceanography 22:108-117

Kopp C, Pernice M, Domart-Coulon I, Djediat D and others (2013) Highly dynamic cellular-level response of symbiotic coral to a sudden increase in environmental nitrogen. MBio 4:e00052-13

Lema KA, Willis BL, Bourne DG (2012) Corals form characteristic associations with symbiotic nitrogen-fixing bacteria. Appl Environ Microbiol 78:3136-3144

Lema KA, Willis BL, Bourne DG (2014) Amplicon pyrosequencing reveals spatial and temporal consistency in diazotroph assemblages of the Acropora millepora microbiome. Environ Microbiol (in press) doi:10.1111/14622920.12366

> Lesser MP, Mazel CH, Gorbunov MY, Falkowski PG (2004) Discovery of symbiotic nitrogen-fixing cyanobacteria in corals. Science 305:997-1000

Lesser MP, Falcón LI, Rodríguez-Román A, Enríquez S, Hoegh-Guldberg O, Iglesias-Prieto R (2007) Nitrogen fixation by symbiotic cyanobacteria provides a source of nitrogen for the scleractinian coral Montastraea cavernosa. Mar Ecol Prog Ser 346:143-152

Levitan O, Rosenberg G, Setlik I, Setlikova E and others (2007) Elevated $\mathrm{CO}_{2}$ enhances nitrogen fixation and growth in the marine cyanobacterium Trichodesmium. Glob Change Biol 13:531-538

Lewis E, Wallace D (1998) Program developed for $\mathrm{CO}_{2}$ system calculations. Carbon Dioxide Information Analysis Center, Oak Ridge National Laboratory, US Dept Energy, ORNL/CDIAC-105 Oak Ridge, TN

Marubini F, Barnett H, Langdon C, Atkinson M (2001)

Editorial responsibility: Peter Edmunds,

Northridge, California, USA
Dependence of calcification on light and carbonate ion concentration for the hermatypic coral Porites compressa. Mar Ecol Prog Ser 220:153-162

Mascarelli PE, Bunkley-Williams L (1999) An experimental evaluation of the healing in damaged, unbleached and artificially bleached star coral, Montastraea annularis. Bull Mar Sci 65:577-586

McNary JE, Burris RH (1962) Energy requirements for nitrogen fixation by cell-free preparations from Clostridium pasteurianum. J Bacteriol 84:598-599

Mohamed NM, Colman AS, Tal Y, Hill RT (2008) Diversity and expression of nitrogen fixation genes in bacterial symbionts of marine sponges. Environ Microbiol 10: 2910-2921

> Muscatine L, Porter JW (1977) Reef corals: mutualistic symbioses adapted to nutrient-poor environments. Bioscience 27:454-460

> Naumann MS, Niggl W, Laforsch C, Glaser C, Wild C (2009) Coral surface area quantification - evaluation of established techniques by comparison with computer tomography. Coral Reefs 28:109-117

> Nohrstedt HÖ (1983) Conversion factor between acetylene reduction and nitrogen fixation in soil: effect of water content and nitrogenase activity. Soil Biol Biochem 15:275-279

Olson ND, Lesser MP (2013) Diazotrophic diversity in the Caribbean coral, Montastraea cavernosa. Arch Microbiol 195:853-859

> Orr JC, Fabry VJ, Aumont O, Bopp L (2005) Anthropogenic ocean acidification over the twenty-first century and its impact on calcifying organisms. Nature 437:681-686

R Development Core Team (2013) R: a language and environment for statistical computing. R Foundation for Statistical Computing, Vienna

Riahi K, Grübler A, Nakicenovic N (2007) Scenarios of longterm socio-economic and environmental development under climate stabilization. Technol Forecast Soc Change 74:887-935

> Ries JB, Cohen L, McCorkle DC (2009) Marine calcifiers exhibit mixed responses to $\mathrm{CO}_{2}$-induced ocean acidification. Geology 37:1131-1134

Shashar N, Cohen Y, Loya Y, Sar N (1994a) Nitrogen fixation (acetylene reduction) in stony corals: evidence for coralbacteria interactions. Mar Ecol Prog Ser 111:259-264

Shashar N, Feldstein T, Cohen Y, Loya Y (1994b) Nitrogen fixation (acetylene reduction) in a coral reef. Coral Reefs 13:171-174

Sheppard CRC (1987) Coral species of the Indian Ocean and adjacent seas: a synonymized compilation and some regional distributional patterns. Atoll Res Bull 307:1-33

Shi D, Kranz SA, Kim J, Morel FMM (2012) Ocean acidification slows nitrogen fixation and growth in the dominant diazotroph Trichodesmium under low-iron conditions. Proc Natl Acad Sci USA 109:E3094-E3100

Wilkinson CR, Fay P (1979) Nitrogen fixation in coral reef sponges with symbiotic cyanobacteria. Nature 279:527-529

> Williams WM, Broughton V, Broughton WJ (1987) Nitrogen fixation (acetylene reduction) associated with the living coral Acropora variabilis. Mar Biol 94:531-535

Wilson ST, Böttjer D, Church MJ, Karl DM (2012) Comparative assessment of nitrogen fixation methodologies, conducted in the oligotrophic North Pacific Ocean. Appl Environ Microbiol 78:6516-6523

Zuberer DA, Silver WS (1978) Biological dinitrogen fixation (acetylene reduction) associated with Florida mangroves. Appl Environ Microbiol 35:567-575

Submitted: April 11, 2014; Accepted: June 10, 2014

Proofs received from author(s): August 18, 2014 